\title{
Evaluation of renal function in patients with psoriasis using immunobiologicals
}

\author{
Avaliação da função renal de pacientes com psoríase em uso de imunobiológicos
}

\author{
Sarah Suyanne Carvalho Melgaço ${ }^{1}$ \\ Amanda Maria Menezes Dantas ${ }^{3}$ \\ Verônica Riquet de Siqueira ${ }^{4}$ \\ Elizabeth de Francesco Daher ${ }^{6}$
}

\author{
Geraldo Bezerra da Silva Junior ${ }^{2}$ \\ Ana Mirella Arcanjo Vasconcelos ${ }^{4}$ \\ Ana Patrícia Freitas Vieira ${ }^{5}$
}

\begin{abstract}
The aim of this study was to evaluate renal function in patients with psoriasis using immunobiologicals. A prospective study was conducted with 15 patients with confirmed diagnosis of psoriasis who were starting to use immunobiologicals. The mean age was $41 \pm 11$ years, with $60 \%$ females. The mean time of disease was $11 \pm 6.6$ years. Significant changes in creatinine and creatinine clearance were not observed in the course of the study. There was an increase in transaminases and a decrease in magnesium levels.
\end{abstract}

Keywords: Drug toxicity; Immunosuppressive agents; Psoriasis; Renal insufficiency; Transaminases

Resumo: O objetivo deste estudo é avaliar a função renal de pacientes com psoríase em uso de imunobiológicos. Foi realizado estudo prospectivo com 15 pacientes com diagnóstico confirmado de psoríase, que iniciariam o tratamento com algum imunobiológico. A média de idade foi de $41 \pm 11$ anos, sendo $60 \%$ do sexo feminino. O tempo médio de doença era de $11 \pm 6,6$ anos. Não foram evidenciadas alterações significativas nos valores de creatinina sérica e/ou do clearance de creatinina durante o estudo. Houve aumento das enzimas hepáticas e redução dos níveis de magnésio.

Palavras-chave: Imunossupressores; Insuficiência renal; Psoríase; Toxicidade de drogas; Transaminases

In dermatology the only disease in which the use of immunobiologicals is permitted is psoriasis, with infliximab, adalimumab and etanercept being the commonest used.1.3

Infliximab has the most common adverse reactions associated with drug infusion such as urticaria, fever, blood pressure fluctuation, anaphylaxis and infections. ${ }^{4,5}$ Hepatic toxicities are reported as an uncommon side effect of this drug. ${ }^{6}$
The most common adverse effects of Etanercept are local reactions in the site of injection, respiratory infections and headaches. ${ }^{4}$ Adverse effects of Adalimumab include local reactions and infections. ${ }^{6}$ Another substantial reaction to the treatment of TNF$\alpha$ inhibitors is the exacerbation of heart failure. ${ }^{5,7}$

Renal effects of immunobiologicals are seldom described. ${ }^{4}$ Probable cases of glomerulonephritis and nephritic syndrome induced by immunobiologicals

Received on 01.08.2012.

Approved by the Advisory Board and accepted for publication on 17.08.2012.

* Study conducted at the Faculty of Medicine, Federal University of Ceará (UFC) - Fortaleza (CE), Brazil.

Conflict of interest: None

Financial support: CNPq

Medical Doctor, graduate of the Federal University of Ceará - Fortaleza (CE), Brazil

Master's Degree in Medical Sciences at the Federal University of Ceará, Assistant Professor, University of Fortaleza - Fortaleza (CE), Brazil.

Medical Doctor, graduate of the Federal University of Ceará - Fortaleza (CE), Brazil.

Medical Doctor, Dermatology Resident at the Walter Cantídio University Hospital, Federal University of Ceará - Fortaleza (CE), Brazil.

Medical Doctor, graduate of the Federal University of Ceará - Fortaleza (CE), Brazil.

Doctorate in Nephrology from the University of São Paulo, Associate Professor, Department of Internal Medicine, Federal University of Ceará - Fortaleza (CE), Brazil. 
have been observed in patients treated for rheumatoid arthritis, juvenile arthritis psoriasis and psoriasis. ${ }^{8-10}$ The present study aimed to evaluate the effect of immunobiologicals in the renal function of patients with psoriasis.

A prospective study to evaluate renal function was conducted in an out patient clinic with 15 patients with confirmed diagnosis of psoriasis and using immunobiologicals (infliximab, adalimumab, etanercept).

Patients of both genders, aged 18-69 years, with confirmed diagnosis of psoriasis (severity area - PASI $>10$ for at least 6 months, non-responders to topical therapy) were included.

Patients with previous systemic therapy (acicretin, methotrexate or cyclosporine) using nephrotoxic drugs and with chronic kidney disease were excluded. Laboratory evaluation was done before and after the use of immunobiologicals.

The patients mean age was $41.7 \pm 11.6$ years, with $60 \%$ female. The mean time of disease was $11.1 \pm 6.6$ years. The main immunobiologicals used were infliximab (40\%) and etanercept $(40 \%)$, in doses of $400 \mathrm{mg}$ and $50 \mathrm{mg}$ respectively.

At the first medical consultation, total blood count and the following were all normal: lipidogram, $\mathrm{Na}, \mathrm{K}, \mathrm{Ca}, \mathrm{Mg}$, serum proteins, amilase, AST, ALT, alkalyne phosphatase, GGT, urea, creatinine, $24 \mathrm{~h}$ proteinuria, microalbuminuria, creatinine clearance, urinalysis, FENa, FEK, torax radiography, PPD, antinuclear antibodies, serologies for viral hepatitis/syphilis/CMV. There were no significant abnormalities in the values of serum creatinine or creatinine clearance during the use of immunobiologicals.

The mean value of AST before the use of immunobiologicals was $24.5 \pm 6.08 \mathrm{IU} / \mathrm{L}$, while during treatment it was $162.6 \pm 469.2 \mathrm{IU} / \mathrm{L}$. The mean value of ALT before the use of immunobiologicals was $24.1 \pm 8.8 \mathrm{IU} / \mathrm{L}$ and $148 \pm 410 \mathrm{IU} / \mathrm{L}$ during treatment.

During the study period two patients were withdrawn from infliximab due to acute hepatitis. Both patients were also using isoniazid for tuberculosis prophylaxis.

The mean value of serum magnesium levels before the use of immunobiologicals was $2.0 \pm 0.26$ $\mathrm{mg} / \mathrm{dL}$, and during treatment $1.7 \pm 0.19 \mathrm{mg} / \mathrm{dL}$. The mean value of tryglicerides before treatment was $133.2 \pm 73.5 \mathrm{mg} / \mathrm{dL}$ while during treatment it was $174.9 \pm 130.1 \mathrm{mg} / \mathrm{dL}$. The mean value of serum $\mathrm{K}$ before treatment was $4.3 \pm 0.32$ and $4.1 \pm 0.27$ during treatment.

The mean value of FEK before treatment was $46.23 \pm 28.19 \%$. After treatment it was $35.6 \pm 11.79 \%$.

The mean creatinine clearance before treatment was $106.18 \pm 33.9 \mathrm{~mL} / \mathrm{min}$. During treatment the minimum creatinine clearance was $103.28 \pm 33.23 \mathrm{~mL} / \mathrm{min}$, while the maximum creatinine clearance was
$117.87 \pm 40.5 \mathrm{mg} / \mathrm{dL}$

The initial mean microalbuminuria was $6.33 \pm 5.47 \mathrm{mg} /$ day. During treatment the minimum microalbuminuria was $5.89 \pm 5.39 \mathrm{mg} /$ day and the maximum $8.36 \pm 6.28 \mathrm{mg} /$ day.

The comparison of laboratory tests before and after the use of immunobiologicals showed as significant changes an increase in liver enzymes (AST, ALT) and decreased levels of magnesium (Mg), as summarized in table 1 . There was also a trend towards increased triglycerides and serum potassium (Table 1).

There was no significant change in creatinine clearance or microalbuminuria before and after treatment (Table 2).

Whereas some studies have shown renal abnormalities after the use of immunobiologicals, the present study did not show significant renal function changes after the use of immunobiologicals. ${ }^{4,8,9,10}$ There was a tendency for potassium levels to decrease.

An important increase in liver enzymes was noted during treatment, with some cases of acute hepatitis. These patients were using infliximab. It was not possible to establish the relationship between inflix-

TABLE 1: Comparison of laboratory tests of 15 patients with psoriasis followed up in an outpatient clinic, before and after the use of immunobiologicals

\begin{tabular}{|c|c|c|c|}
\hline & Pre-treatment & Post-treatment & $\mathbf{P}$ \\
\hline $\mathrm{Hb}(\mathrm{g} / \mathrm{dL})$ & $14.1 \pm 1.8$ & $14.6 \pm 1.5$ & 0.14 \\
\hline Ht $(\%)$ & $42.2 \pm 4.3$ & $43.3 \pm 4.4$ & 0.27 \\
\hline White blood count (mm3) & $6977 \pm 1886$ & $6331 \pm 2328$ & 0.27 \\
\hline Platelets (mm3) & $250000 \pm 57909$ & $245700 \pm 38511$ & 0.79 \\
\hline ESR (mm) & $22 \pm 19$ & $23 \pm 17$ & 0.73 \\
\hline Total Cholesterol (mg/dL) & $197 \pm 56$ & $194 \pm 46$ & 0.73 \\
\hline HDL (mg/dL) & $43 \pm 12$ & $44 \pm 14$ & 0.61 \\
\hline LDL (mg/dL) & $131 \pm 43$ & $114 \pm 39$ & 0.29 \\
\hline Triglycerides (mg/dL) & $140 \pm 82$ & $190 \pm 129$ & 0.05 \\
\hline Fast Glucose $(\mathrm{mg} / \mathrm{dL})$ & $74 \pm 23$ & $85 \pm 16$ & 0.33 \\
\hline C-reactive protein $(\mathrm{mg} / \mathrm{dL})$ & $2.5 \pm 5.3$ & $0.8 \pm 1.2$ & 0.38 \\
\hline $\mathrm{Na}(\mathrm{mEq} / \mathrm{L})$ & $138 \pm 3.5$ & $137 \pm 4.8$ & 0.67 \\
\hline $\mathrm{K}(\mathrm{mEq} / \mathrm{L})$ & $4.2 \pm 0.3$ & $4.1 \pm 0.2$ & 0.09 \\
\hline $\mathrm{Ca}(\mathrm{mg} / \mathrm{dL})$ & $9.0 \pm 0.4$ & $8.9 \pm 0.5$ & 0.43 \\
\hline $\mathrm{Mg}(\mathrm{mEq} / \mathrm{L})$ & $2.0 \pm 0.3$ & $1.7 \pm 0.1$ & 0.01 \\
\hline Urea (mg/dL) & $26 \pm 8.0$ & $27 \pm 10$ & 0.84 \\
\hline Creatinine $(\mathrm{mg} / \mathrm{dL})$ & $0.78 \pm 0.11$ & $0.79 \pm 0.17$ & 0.8 \\
\hline Albumin $(\mathrm{g} / \mathrm{dL})$ & $4.21 \pm 0.35$ & $4.26 \pm 0.27$ & 0.27 \\
\hline Globulins $(\mathrm{g} / \mathrm{dL})$ & $3.0 \pm 0.5$ & $2.9 \pm 0.5$ & 0.69 \\
\hline AST (IU/L) & $24.5 \pm 6.08$ & $162.6 \pm 469.2$ & 0.0001 \\
\hline ALT (IU/L) & $24.1 \pm 8.8$ & $148 \pm 410$ & 0.0001 \\
\hline Amilase (IU/L) & $65 \pm 21$ & $73 \pm 32$ & 0.35 \\
\hline
\end{tabular}


TABLE 2: Comparison of laboratory tests for renal function of 15 patients with psoriasis followed in an outpatient clinic, before and after the use of immunobiologicals

\begin{tabular}{llll}
\hline & Pre-treatment & Post-treatment & P \\
Creatinine Clearance & $90.02 \pm 41.6$ & $95.31 \pm 38.77$ & 0.85 \\
Microalbuminuria & $5.6 \pm 2.9$ & $10.7 \pm 7.1$ & 0.14 \\
FEK \% & $40.27 \pm 26.25$ & $35.36 \pm 12.9$ & 0.63 \\
Urine specific gravity & $1015 \pm 3.6$ & $1013 \pm 5.1$ & 0.5 \\
Urine pH & $5.8 \pm 0.7$ & $5.9 \pm 0.7$ & 0.76 \\
\hline
\end{tabular}

imab and hepatotoxicity given that these patients were also using isoniazid, a potentially hepatotoxic drug, used in tuberculosis prophylaxis.

A significant fall in the levels of serum magnesium was also observed, but the urinary magnesium was not measured, so that it was not possible to assess associated hypermagnesiuria.

\section{REFERENCES}

1. Díaz-Ley B, Guhl G, Fernández-Herrera J. Off-label use of biologic agents in the treatment of dermatosis, Part 1: Infliximab and adalimumab. Actas Dermosifiliogr. 2007;98:657-78.

2. Lee R, Cooper AJ. Biologic agents in psoriasis. Australas J Dermatol. 2006;46: 217-30.

3. Sobell JM. Overview of biologic agents in Medicine and Dermatology. Semin Cutan Med Surg. 2005;24:2-9.

4. Schiff MH, Whelton A. Renal toxicity associated with disease-modifying antirheumatic drugs used for the treatment of rheumatoid arthritis. Semin Arthritis Rheum. 2000;30:196-208.

5. Moraes JCB, Aikawa NE, Ribeiro ACM, Saad CGS, Carvalho JF, Pereira RMR, Silva CAA, Bonfá E. Complicações imediatas de 3555 aplicações de agentes anti-TNF $\alpha$. Rev Bras Reumatol. 2010;50:165-70.

6. Zeichner JA, Lebowhl M. Potential complications associated with the use of biologic agents for psoriasis. Dermatol Clin. 2007;25:207-13.

7. Torres T, Velho GC, Sanches M, Selores M. Psoríase na era dos biológicos. Acta Med Port. 2010;23:493-8.

8. Menè P, Franeta AJ, Conti G, Stoppacciaro A, Chimenz R, Fede A, et al. Extracapillary glomerulonephritis during etanercept treatment for juvenile psoriatic arthritis. Clin Exp Rheumatol. 2010;28:91-3.

9. Stokes MB, Foster K, Markowitz GS, Ebrahimi F, Hines W, Kaufman D, et al. Development of glomerulonephritis during anti-TNF $\alpha$ therapy for rheumatoid arthritis. Nephrol Dial Transplant. 2005;20:1400-6.

10. Chin G, Luxton G, Harvey JM. Infliximab and nephritic syndrome. Nephrol Dial Transplant. 2005;20:2824-6.
The electrolyte abnormalities found suggest possible tubular nephrotoxicity caused by the immunobiologicals. We believe that more specific studies should be undertaken in order to better investigate renal tubular changes induced by immunobiologicals.

\author{
MAILING ADDRESS: \\ Geraldo Bezerra da Silva Junior \\ Rua Vicente Linhares, 1198 - Aldeota \\ 60135-270 - Fortaleza - CE \\ Brazil \\ E-mail: geraldobezerrajr@yahoo.com.br
}

How to cite this article: Melgaço SSC, Silva GB Jr, Dantas AMM, Vasconcelos AMA, Siqueira VR, Vieira APF, Daher EF. Evaluation of renal function in patients with psoriasis using immunobiologicals. An Bras Dermatol. 2013;88(4):667-9. 